\title{
THE PEDAGOGY OF MEMORIAL SITES
}

\author{
LUIZA KOŃCZYK \\ luiza.konczyk@gmail.com \\ University of Wrocław, Poland
}

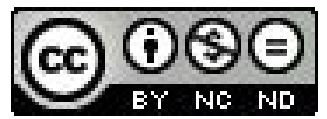

\begin{abstract}
Memorial site pedagogy is a term describing the practice and theory of historico-political education in museums in former nazi concentration camps. It combines gaining and deepening historical knowledge on the topic of World War II with self-development and shaping socially desirable attitudes, through usage of non-formal educational methods. Pedagogy of memorial sites aims at, among other things, learning tolerance and respect for diversity and shaping reflective and active members of society. It offers an answer to the needs of contemporary European societies in the area of strengthening democratic attitudes.
\end{abstract}

Key words: memorial site pedagogy, memorial site, culture of remembrance, historico-political education, intercultural education, human rights education, tolerance, diversity, Holocaust

The history of Europe in the $20^{\text {th }}$ century was marked by two world wars and two totalitarian systems: communism and national socialism. These two systems, despite ideological differences, used similar means to reach their goals - violence and terror. Work camps and concentration camps are their symbols. After World War II, during the process of Germany dealing with its past, these camps, former nazi camps in particular, have gained new meanings and begun to fulfill new functions. Museums, which were created in the areas of former concentration and extermination camps, being a special kind of cemeteries, became also memorials of the past, commemorating victims of the regime. A new field of educational work, unknown until then, was naturally born in this area - the pedagogy of memorial sites.

The pedagogy of memorial sites is a term which has been in use for a quite short time in Polish pedagogical practice and theory. Before it was published in the Pedagogical Encyclopedia of the $21^{\text {st }}$ century, edited by Tadeusz Pilch (Kranz 2003a, p. 410), it was mainly used by Tomasz Kranz, the director of State Museum at Majdanek, in his publications. He is the author of one of only a few polish books about education related to memorial sites: Historical education in memorial sites. Key issue outline, published by Kalwińska (2002). Some articles describing memorial site pedagogy or education at former concentration camps have appeared in a bulletin "Past and Memory" (Kranz 2003b, p. 9), which is published by the Fight and Martyrdom Memory Protection Council. But especially cohesive publications are lacking, which would deal with topics of theory and practice of memorial site pedagogy. It might be surprising, particularly taking into account the fact, that Poland is an area rich in places, which have an important historical meaning, "remember" the happenings of World War II and commemorate victims of Nazism. These are the places in which memorial site pedagogy has grown and is now developing. 
To present this area of educational practice and theory, I would like to start with an attempt to give some order to the apparent conceptual vagueness. Little academic reflection on memorial site pedagogy results in an insufficiently developed system of terms in this field of polish educational theory. The term "memorial site pedagogy" is undefined itself. Some studies suggest that "memorial site pedagogy" and "memorial pedagogy" are identical (Kranz 2005, p. 171), which results in them being used interchangeably. These ambiguities may appear due to the fact, that the terminology in the field of memorial site pedagogics is translated from German language. The term "memorial site pedagogics" corresponds with German Gedenkstaettenpaedagogik, at the same time being its literal translation (Gedenkstaette from German- memorial site). In German literature on the topic there are also two other related terms: Erinnerungskultur and Gedenkkultur, which mean "culture of remembrance". It is not only connected to the matters of commemoration of victims and happenings of World War II, but also, according to Nicolas Berg, it applies to all social individuals (Berg 1996, p. 131), which operate in this area of culture. This is the way T. Kranz understands the culture of remembrance. He thinks that these are "texts and forms characteristic for a society, which apply to cultivation of memory about past happenings. (...) It includes not only generally accepted figures and historical happenings, which are a subject of social commemoration, but also commonly established symbols and rituals, which are used to express outwardly attitudes towards the past" (2002, p. 129) ${ }^{1}$. This means, that the culture of remembrance refers to the past in general, and is expressed by collective and individual "remembering". Therefore commemoration of extermination sites is a part of culture of remembrance. By analogy one could state, that memorial site pedagogy represents a particular field in memorial pedagogy, where the interest in the latter concerns the past in a wider sense. This differentiation I propose and consider to be important, particularly because of an individual attitude towards educational work in former concentration camps, demanded by the practitioners and theoreticians in this field. It is caused by the delicacy of the topic, its horrible nature, number and complexity of touched matters (Totten 2001, p. 2-3). This differentiation is also important because, in my reflection, I only focus on memorial site pedagogy in narrow understanding- concerning the legacy of national socialism, to presents its particular character and educational potential.

To clarify what memorial site pedagogy is, it is essential to understand what memorial sites themselves are. Here some discrepancies in terminology are also observable. One of the ways to understand memorial sites is to recognize them as certain, topographically specified places, like cities, regions or rivers (Weber 2008, p. 2) $)^{2}$. As Matthias Weber points out, "a memorial, a concentration camp, a burial place or a monument can also be a site which is anchored in a particular manner in memory" $(2008$, p. 2). It is not the only way to define a memorial site. In a wider, metaphorical depiction, French historian, Pierre Nora, acknowledges as memorial

\footnotetext{
11 translations are made by the author of the article.

This way of understanding memorial sites was used during a conference "Sites of Memory in Central Europe - Experiences of the Past and Perspectives", taking place from $11^{\text {th }}$ to $13^{\text {th }}$ January 2008 in Warsaw.
} 
sites also "historical events, personages, institutions, books, works of art and other cultural artifacts, historical dates or terms" (Weber 2008, p. 2). According to that, a statement made by Étienne François and Hagen Schulze seems to be justified, that in a wide understanding, memorial sites are "long-lasting, focal points of collective memory and identity which survive over generations" (Weber 2008, p. 2) Therefore they are historical points of reference which help us to orientate while building an individual-group relation, through creating collective memory and later its internalization, which influences the identity building process. T. Kranz, the principal Polish theoretician in the field of memorial site pedagogy, underlines that "in the practical sphere, memorial site pedagogy develops most of all as a part of work of museums in former concentration camps and out-of-school education conducted by different educational institutions" (Kranz 2010, p. 35). Thus, in a narrow depiction memorial sites are most of all former concentration camps or extermination camps, which areas are now used as museums, and places connected to them such as: sub camps, memorials, places of execution, cemeteries. Their aim is "commemoration of victims of national socialistic terror and crimes (...), and also soldiers killed in fighting" (Kranz 2002, p. 129). Thus memorial sites in a wide depiction, suggested by P. Nora, may be the subject of educational activities in the area of memorial pedagogy. Whereas memorial sites, according to T. Kranz, are a space where memorial site pedagogy develops. In my reflection I am making use of this narrow understanding of memorial sites. In Poland the above described museum complexes used to be, and partly still are, called martyrological museums, so "museums commemorating martyrdom and suffering of the polish nation" (Meyer zu Uptrup 1998, p. 163), because they were connected to "political legitimization strategy, which together with the breakthrough of 1989-1990 became an anachronism" (Meyer zu Uptrup 1998, p. 163). This has significantly limited the extent of didactical activities conducted by these institutions. For that reason, gradually from year 1989, the name "martyrological museums" is being exchanged for "memorial sites", which, at the same time, broadens the range of pedagogical scope - in the case of historico-political education, democracy education and intercultural education.

To understand the essence of memorial site pedagogy, it is crucial to learn about its beginnings which are directly connected with work of the German organization Action Reconciliation Service for Peace (ARSP). This organization was founded by the synod of the Evangelical Church in Germany, in May 1958. Its aim was redressing and an attempt to reconciliation with countries particularly afflicted by violence of the Third Reich during World War II. This was supposed to be achieved through "actions" - good deeds, for example: young German volunteers doing conservation work at the former concentration camp areas or taking part in building socially useful institutions (Skriver 1962, p. 13-15). Starting in the 60s, ARSP had been organizing study tours to Poland, which was the starting point for the development of the educational practice in memorial sites. These visits had a special value to $A R S P$, as steps on the way to transform the historical awareness of Germans and as impulses forming desired (democratic) socio-political attitudes. Education in memorial sites consisted of: learning history - mainly in a form of own research based on available resources (for example: movies, documents, 
archives, pictures) and meetings with former prisoners and also conservation works at the memorial sites. Additionally it has also contributed to a warming up of Polish-German relations. One of the initiatives supported by ARSP was the establishment of the International Youth Meeting House in Oświęcim (IYMH), Poland (based on numerous examples of German Jugendbegegnungsstaetten- youth meeting houses), which is a place of a dialogue about "history, as well as a [place] to discuss the present, which should lead to breaking down prejudices and support international and intercultural dialogue" (Kranz 2002, p. 50-51). The work of IYMH is mainly focused on organization of seminars, conferences, workshops and international projects in the area of historico-political education.

That is the way memorial site pedagogy has developed on the practical level. On the philosophical level it reaches to the works of German sociologist and philosopher Theodor Adorno, who in his famous essay Education after Achuschwitz reflects on challenges of pedagogy in the face of the struggle with the legacy of national socialism. Already in the first sentence of his text T. Adorno formulates an assumption that: "The premier demand upon all education is that Auschwitz not happen again" (2003, p. 19). According to philosopher, humans have a natural susceptibility to barbarian behavior which is being eliminated through education. Therefore, it is important to analyze the mechanisms of crime and conducting such educational activities which would lead to shaping autonomous and self-critical individuals, who reflectively look back at the past and themselves. Additionally, T. Adorno points out, that genocide is a result of nationalism which appeared in many European countries at the end of the $19^{\text {th }}$ century (2003, p. 19-20). Counteracting the "side effects" of nationalism - xenophobia, racism and other forms of discrimination will also appear among the most important demands of memorial site pedagogy.

Considering the guidelines of T. Adorno, according to T. Kranz, general aims of memorial site pedagogy are: "enabling to gain and to absorb knowledge about history of the place, taking into consideration the general historical background and then initiating the thought process in the context of discovered figures, events and processes". Specific aims "are connected to activation and organization of the cognitive process, and thence with generating observations, which may have a normative meaning for the internal development of a human. This should make orientation in the world easier and prompt towards social activity" (Kranz 2005, p. 173). Annegret Ehmenn also includes within memorial site pedagogy's objectives emancipation, learning to think critically and development of empathy (Ehmann 2000, p. 189). An additional aim is influencing attitudes and in this way shaping individuals who are tolerant of diversity, nonconformist and reflective. For this reason the content of education in memorial sites tries to combine deepening historical knowledge with self-development of an individual and shaping socially desirable attitudes. Thus, the subjects of this kind of education should include from: "learning tolerance, through building a system of moral values, to understanding the question of human rights and social justice. It is mostly about counteracting discrimination, breaking down prejudices, knowing how to deal with cases of aggression and violence, creating awareness of the dangers resulting from social indifference and creating behavior based on sensitivity and tolerance" (Kranz 2005, p. 173). 
Memorial site pedagogy does not have a separate theory of didactic, however, based on observations of practical educational work in memorial sites, Dirk Lange has separated three basic forms of learning:

- Presentation of basic facts;

- Learning about the reasons for past happenings;

- Revealing analogies to today's problems (Lange 2006, p. 13).

Presentation of the facts will lead to a reflection on injustice, which was an integral element of national socialism. Connected to this are questions of discrimination, anti-semitism, racism and cultural, ethnic or national diversity. It is supposed to be a reminder of the fact that all people are equal which is the basis to learning about human rights and intercultural education. Learning about the reasons for the past consists of showing historical connections and relating them to democracy and threats to it (for example: reflection on Germany's situation after the World War I shows how easily a totalitarian system may succeed). Making analogies to today's problems is linked to a very important task of memorial site pedagogy-orientation in the present and shaping the future perspective. It does bring the risk of comparison which may result in relativizing past happenings. If, however, direct comparisons are avoided and only conclusions are drawn from history, then based on the past a future may be built (Lange 2006, p. 14-15), in which "Auschwitz not happen again" (Adorno 2003, p. 19).

For the education in memorial sites to be successful, there is a need for the methodology of work to be adjusted to the characteristic of the place of learning. T. Kranz, in his reflections, claims that memorial site pedagogy should be based on the following methodological criteria:

- Authentication of historical process - visual presentation;

- Enabling identification possibilities - situational focus;

- Enabling to transmit the feelings and knowledge into today's world-transfer (Kranz 2002, p. 66).

Visual presentation means showing historical facts - not listed, but through activating the participants of the educational process to get the knowledge themselves, to look for answers on their own. Situational focus means making references to experiences of the learners. It indicates also showing individual stories (both prisoners, and perpetrators) in a wider, historical context, to make it possible to empathize with the victims and to deeper understand the presented situations. Transfer is an attempt to "define normative meaning of the past for the future" (Kranz 2002, p. 66), thus relating past happenings and emotional experiences connected to learning about them to today's personal, social and global situation.

An institution which is realizing the objectives of memorial site pedagogy is, the already mentioned, IYMH in Oświęcim. Besides Stutthof and State Museum at Majdanek, it is one of the most actively working educational organizations in this field. IYMH in Oświęcim uses methods and forms of learning in memorial sites, which have been described above, at the same time following methodological criteria proposed by T. Kranz. To better understand how these methodological criteria are transferred into practical actions and also to demonstrate the forms of 
work in IYMH in Oświęcim, I will briefly present three examples of methods used there, which were applied at the international youth summer camp organized by ARSP which took place from $16^{\text {th }}$ to $29^{\text {th }}$ August 2010.

IYMH in Oświęcim is located close to former concentration camp Auschwitz. One of the main educational elements in this institution is a visit to the Auschwitz-Birkenau State Museum. The group is shown around by a professional guide and learns about the history of World War II through history of the camp and its former prisoners. In literature on this topic it is underlined, that a special aura in former concentration camps is there to observe. T. Kranz suggests that it is caused by the unusual character of these places, as they are fragments of historical happenings and they "create a kind of bridge between past and present reality" (Kranz 2002, p. 40). Visiting a memorial site is not a method in itself. It is additional to workshops conducted in IYMH. Workshops enable students to prepare for a visit at a memorial site, which might be a strong emotional experience. During the preparation workshops participants may be posed questions, to which they should find answers in the Auschwitz-Birkenau State Museum (the content of the questions depends on the main topic of a seminar or a project - its aim is activating a self-learning process). Workshops after the visit in a memorial site offer a possibility to share experienced emotions, observations and later deepen knowledge using methods of non-formal education. Active methods, in which a relation to participant's experiences is made, are an example of a visual presentation of the historical process which, according to T. Kranz, is one of the methodological criteria of educational work in memorial sites.

Other, commonly used method, derived from ARSP practices, are voluntary conservation works at the memorial sites. Since such work within the area of the Auchwitz-Birkenau State Museum is not possible, IYMH offers a possibility to work at an old Jewish cemetery in Oświęcim. This place is a symbol of past Jewish life in Oświęcim and at the same time an area directly connected to happenings of World War II. Physical work might be an alternative to workshops dealing with difficult topics and also a kind of respite from the intensive thought processes. At the same time it creates a feeling of a responsibility for the place and a relation to it. It is particularly important due to the passage of time, which causes a weakening of personal attitude of the visitors towards memorial sites, resulting in smaller influence possibilities (Lutz 1995, p. 17). Physical work having tangible effects, may invoke a feeling of causativeness and awareness, and that one's personal involvement can lead to measurable effects. It is important in the case of pedagogy demanded by the memorial sites drawing analogies to the present and working for the future.

The third memorial site pedagogy method presented is "eye-witness talks". "Eye-witness" is an expression originating from the German language and is commonly used to describe former prisoners of concentration camps. Talks with the witnesses usually begin with them telling their stories or history of the camp, in which they were imprisoned. After that, there is a time for participants to ask questions. According to Dori Laub, a person who listens to stories about such traumatic experiences, is confronted every time with a unique situation. Despite many books or movies about the topic, only a meeting with an individual, who has experienced a 
concentration camp, gives the listeners a feeling of somehow participating in these happenings and re-living them (Laub 2000, p. 68). It involves elements of visual presentation, being an original way of gaining knowledge, enriched by a possibility to ask questions to the direct witnesses of the happenings. At the same time, it recreates the criteria of situational focus, through presentation of individual stories. It is a form of usage of oral history method, specific, because it implies a direct meeting with another person which, because of the passing time, will soon not be possible.

World War II- experiences so painful, that in cognitive awareness it might be difficult to go back, have shaped today's Europe and will indirectly influence future happenings. A particularly painful element is the Holocaust and it "shall (...) be recognized as a happening of universal character and humanity-wide dimension, a European legacy and experience, which should have influence on shaping the historical awareness and political culture of today's nations" (Kranz 2002, p. 20). The Holocaust is not only a genocide of the Jewish nation, but also an example of what discrimination, racism, xenophobia and radical nationalism may lead to. These problems are also present now, especially in face of intense migrations, which result in a growing cultural diversity. Currently a lot of emphasis is placed on intercultural education, democracy education or human rights education. The potential of memorial site pedagogy in this area is also worth recognizing. Its aim is shaping an autonomous and reflective individual, actively taking part in social life, living in the spirit of tolerance. It is particularly important taking into account the fact, that after World War II, there were several other cases of genocide (for example: the massacre in Srebrenica, and genocide in Rwanda). Also a growth of the presence of right-wing extremists in social space can be observed. The universal character of memorial site pedagogy is underlined by the fact, that it applies to universal values and transfer these values. It may be of help when creating a new concept of modern patriotism, based on tolerance for diversity. Thus memorial site pedagogy, even though based in the past, does not only stay in the past. It is future-orientated and thus states its educational potential for contemporary societies.

\section{BIBLIOGRAPHY}

Adorno T. (2003), Education after Auschwitz, Henry W. Pickford (trans.) [in:] Tiedemann R. (ed.), Can One Live After Auschwitz? A Philosophical Reader, Stanford University Press, Stanford.

Beer U. (ed.), Niemand zeugt fuer den Zeugen. Erinnerungskultur nach der Shoah, suhrkamp, Frankurt.

Berg N. (1996), Auschwitz und die Geschichtswissenschaft- Ueberlegungen zu Kontroversen der letzten Jahre [in:] Berg N., Jochimsen J., Stiegler B. (eds), SHOAH. Formen der Errinerung. Geschichte, Philosophie, Literatur, Kunst, Wilhelm Fink Verlag, Muenchen.

Berg N., Jochimsen J., Stiegler B. (eds), SHOAH. Formen der Errinerung. Geschichte, Philosophie, Literatur, Kunst, Wilhelm Fink Verlag, Muenchen.

Ehmann A. (2000), Auseinandersetzung mit Nationalsozialismus Und Holocaust in der historiach-politischen Bildung. Wo stehen wir-was bleibt-was aendert sich? [in:] Fechler B., Koessler G., Lieberz-Gross T. (eds), Erziehung nach Auschwitz In der multikulturellen Gesellschaft. Paedagogische Und soziologische Annaeherungen, Juventa, Monachium.

Encyklopedia Pedagogiczna XXI wieku, vol. 4, Wydawnictwo Akademickie ŻAK, Warszawa.

Endlich S., Lutz T. (eds), Gedenken Und lernen an historischen Orten, Landeszentrale fuer politische Bildungsarbeit, Berlin.

Fechler B., Koessler G., Lieberz-Gross T. (eds), Erziehung nach Auschwitz In der multikulturellen Gesellschaft. Paedagogische Und soziologische Annaeherungen, Juventa, Monachium. 
Kranz T. (2002), Edukacja historyczna w miejscach pamięci, Stowarzyszenie „Dialog i Współpraca”, Lublin.

Kranz T. (2003a), Uwagi na temat rozwoju działalności pedagogicznej muzeów upamiętniania w Polsce i Niemczech, "Zeszyty Majdanka”, vol. 22.

Kranz T. (2003b), Muzea w byłych obozach w Polsce jako forma instytucjonalizacji pamiecci, „, Eambinowicki Rocznik Muzealny", Opole.

Kranz T. (2005), Pedagogika miejsc pamięci, in: Encyklopedia Pedagogiczna XXI wieku, vol. 4, Wydawnictwo Akademickie ŻAK, Warszawa.

Kranz T. (2010), Pedagogika pamięci, „Nigdy Więcej”, 18.

Kranz T. (ed.), Zbrodnie nazizmu w świadomości i edukacji historycznej w Polsce i Niemczech, Państwowe Muzeum na Majdanku, Lublin.

Lange D. (2006), Politische Bildung an historischen Orten. Vorueberlegungen fuer eine Didaktik des Erinnerns [in:] Lange D. (ed.), Politische Bildung an historischen Orten. Materialen zur Didaktik des Erinnerns, Schneider Verlag Hohengehren, Baltmansweiler.

Lange D. (ed.), Politische Bildung an historischen Orten. Materialen zur Didaktik des Erinnerns, Schneider Verlag Hohengehren, Baltmansweiler.

Laub D. (2000), Zeugnis ablegen oder die Schwierigkeiten des Zuhoerens [in:] Beer U. (ed.), Niemand zeugt fuer den Zeugen. Erinnerungskultur nach der Shoah, suhrkamp, Frankurt.

Lutz T. (1995), Anmerkungen zur Paedagogik in Gedenkstaetten duer die Opfer des Nationalsozialismus [in:] Endlich S., Lutz T. (eds), Gedenken Und lernen an historischen Orten, Landeszentrale fuer politische Bildungsarbeit, Berlin.

Meyer zu Uptrup W. (1998), O roli muzeów upamiętniania utworzonych w miejscach zbrodni nazistowskich w dzisiejszej edukacji politycznej [in:] Kranz T. (ed.), Zbrodnie nazizmu w świadomości i edukacji historycznej w Polsce $i$ Niemczech, Państwowe Muzeum na Majdanku, Lublin.

Skriver A. (1962), Aktion Suehnezeichen. Bruecken ueber Blut Und Asche, Kreuz- Verlag, Stuttgart.

Tiedemann R. (ed.), Can One Live After Auschwitz? A Philosophical Reader, Stanford University Press, Stanford.

Totten S. (ed.) (2001), Teaching Holocaust Literature, Allyn\&Bacon, Boston.

\section{NETOGRAPHY:}

Kalwińska E. (2002), Tomasz Kranz, http://tnn.pl/Tomasz_Kranz,3382.html, retrieved: 7.11.2011.

Weber M. (2008), On the Topic of the Conference "Sites of Memory in Central Europe - Experiences of the Past and Perspectives", http://enrs.eu/images/Teksty\%20pdf\%20ang/Weber_ang.pdf, retrieved: 12.11.2011. 